Research article

Open Access

\title{
A prospective study of androgen levels, hormone-related genes and risk of rheumatoid arthritis
}

\author{
Elizabeth W Karlson 1, Lori B Chibnik1, Monica McGrath², Shun-Chiao Chang ${ }^{3}$, \\ Brendan T Keenan ${ }^{1}$, Karen H Costenbader ${ }^{1}$, Patricia A Fraser ${ }^{4,5}$, Shelley Tworoger ${ }^{2,3}$, \\ Susan E Hankinson ${ }^{2,3}$, I-Min Lee ${ }^{3,6}$, Julie Buring $3,6,7,8$ and Immaculata De Vivo2
}

\author{
1Division of Rheumatology, Immunology, and Allergy, Department of Medicine, Brigham and Women's Hospital and Harvard Medical School, 75 \\ Francis Street, Boston, MA 02115, USA \\ ${ }^{2}$ Channing Laboratory, Department of Medicine, Brigham and Women's Hospital and Harvard Medical School, 75 Francis Street, Boston, MA 02115, \\ USA \\ 3Department of Epidemiology, Harvard School of Public Health, 677 Huntington Avenue, Boston, MA 02115, USA \\ 4 Immune Disease Institute, 800 Huntington Avenue, Boston, MA 02115, USA \\ ${ }^{5}$ Genzyme Corporation, 500 Kendall Street, Cambridge, MA 02115, USA \\ ${ }^{6}$ Division of Preventive Medicine, Department of Medicine, Brigham and Women's Hospital and Harvard Medical School, 75 Francis Street, Boston, \\ MA 02115, USA \\ 7Division of Aging, Department of Medicine, Brigham and Women's Hospital and Harvard Medical School, 75 Francis Street, Boston, MA 02115, \\ USA
}

${ }^{8}$ Department of Ambulatory Care and Prevention, Harvard Medical School, 25 Shattuck Street, Boston, MA 02115, USA

Corresponding author: Elizabeth W Karlson, ekarlson@partners.org

Received: 24 Feb 2009 Revisions requested: 1 Apr 2009 Revisions received: 11 May 2009 Accepted: 25 Jun 2009 Published: 25 Jun 2009

Arthritis Research \& Therapy 2009, 11:R97 (doi:10.1186/ar2742)

This article is online at: http://arthritis-research.com/content/11/3/R97

(c) 2009 Karlson et al.; licensee BioMed Central Ltd.

This is an open access article distributed under the terms of the Creative Commons Attribution License (http://creativecommons.org/licenses/by/2.0), which permits unrestricted use, distribution, and reproduction in any medium, provided the original work is properly cited

\begin{abstract}
Introduction Rheumatoid arthritis (RA) is more common in females than males and sex steroid hormones may in part explain this difference. We conducted a case-control study nested within two prospective studies to determine the associations between plasma steroid hormones measured prior to RA onset and polymorphisms in the androgen receptor $(A R)$, estrogen receptor 2 (ESR2), aromatase (CYP19) and progesterone receptor $(P G R)$ genes and RA risk.
\end{abstract}

Methods We genotyped AR, ESR2, CYP19, PGR SNPs and the $A R$ CAG repeat in RA case-control studies nested within the Nurses' Health Study (NHS), NHS II (449 RA cases, 449 controls) and the Women's Health Study (72 cases, and 202 controls). All controls were matched on cohort, age, Caucasian race, menopausal status, and postmenopausal hormone use. We measured plasma dehydroepiandrosterone sulfate (DHEAS), testosterone, and sex hormone binding globulin in 132 pre-RA samples and 396 matched controls in the NHS cohorts. We used conditional logistic regression models adjusted for potential confounders to assess RA risk.

Results Mean age of RA diagnosis was 55 years in both cohorts; $58 \%$ of cases were rheumatoid factor positive at diagnosis. There was no significant association between plasma DHEAS, total testosterone, or calculated free testosterone and risk of future RA. There was no association between individual variants or haplotypes in any of the genes and RA or seropositive RA, nor any association for the AR CAG repeat.

Conclusions Steroid hormone levels measured at a single time point prior to RA onset were not associated with RA risk in this study. Our findings do not suggest that androgens or the $A R$, ESR2, PGR, and CYP19 genes are important to RA risk in women.

ACR: American College of Rheumatology; AR: androgen receptor gene; CYP19: aromatase gene; DHEAS: dehydroepiandrosterone sulfate; ESR2: estrogen receptor 2 gene; htSNP: haplotype-tagged single nucleotide polymorphism; IL: interleukin; NHS: Nurses' Health Study; PGR: progesterone receptor gene; RA: rheumatoid arthritis; SHBG: sex hormone binding globulin; SNP: single nucleotide polymorphism; TNF: tumor necrosis factor; WHS: Women's Health Study. 


\section{Introduction}

Women are two to four times more likely than men to develop rheumatoid arthritis (RA) [1,2], and sex hormones including androgens, estrogen, and progesterone may be related to this disparity $[3,4]$. In women and men the age-related increased incidence of RA parallels the decline in androgen production [5]. Cross-sectional studies of serum androgen levels demonstrate low serum testosterone levels and dehydroepiandrosterone sulfate (DHEAS) in RA patients compared with healthy individuals [6-10]. Serum testosterone levels are inversely correlated with RA disease activity [11], and DHEAS levels are inversely correlated with both disease duration and clinical severity of RA [12]. Androgen receptor expression is significantly higher in RA synovial tissue compared with that in noninflamed synovial tissue [13]. In synovial fluid from active RA patients compared with control individuals, there is evidence of higher free estrogen, lower free androgen levels, and locally elevated aromatase activity [14]. Small randomized controlled trials of testosterone treatment demonstrate significantly improved RA symptoms in women with RA [15] and in men with RA [16]. Whether low androgen levels precede the onset of RA or are simply the result of the disease or its treatment is not clear. One small prospective study demonstrated low DHEAS among premenopausal pre-RA women compared with control individuals [17], while another study demonstrated no differences in total testosterone or DHEAS levels in male and female pre-RA cases compared with sex-matched control individuals [18].

Androgens have immunosuppressive effects on both the humoral and cellular immune response [19-24]. The female sex predominance in RA may be related to low androgen levels prior to disease onset since adrenal and gonadal androgen deficiency can trigger inflammatory cytokines such as TNF $\alpha$ and IL-6, key cytokines responsible for the inflammatory response in RA [25]. Alternatively, androgens may influence $\mathrm{RA}$ risk indirectly through conversion to estradiol by aromatase or directly by binding to the androgen receptor and affecting cell proliferation. We hypothesized that low total and free testosterone levels and low DHEAS levels measured before the onset of disease would be associated with an increased risk of RA in women.

Excess estrogen and progesterone may have a protective role in RA etiology. Women are at decreased risk of developing RA during pregnancy, when estrogen and progesterone levels are high. The 12-month postpartum period, particularly the first 3 months, represents a period of increased risk, however, when estrogen and progesterone levels fall dramatically [26]. Progesterone, as well as estrogen and androgens, may therefore play a role in RA pathogenesis.

Based on the hypothesis that a low androgen-estrogen balance is associated with RA in women $[3,4]$, we investigated a number of hormone receptor genes involved in androgen- estrogen pathways for association with RA. The estrogen receptor, the androgen receptor and the progesterone receptor are members of the nuclear receptor superfamily, which depend on ligand binding for activation.

The androgen receptor gene $(A R)$ located on chromosome $\mathrm{X}$ encodes the androgen receptor, and upon androgen binding the activated androgen-androgen receptor complex activates the expression of other genes via ligand binding, homodimerization, nuclear translocation, DNA binding, and formation of complexes with co-activators and co-repressors [27]. Exon 1 contains a polymorphic CAG repeat sequence that correlates inversely with $A R$ transactivational activity $[28,29]$. Shorter CAG repeat polymorphisms (more active receptor) in $A R$ are associated with higher serum androgen levels among premenopausal women [30].

When androgens are converted to their corresponding estrogens, the effects are mediated by estrogen receptors 1 and 2 . The estrogen receptor 2 gene (ESR2) is located on chromosome 14q22-24. Estrogen receptors are highly expressed on synovial cells [13] and are found on T lymphocytes [31].

The progesterone gene ( $P G R)$ is a single-copy gene located on chromosome 11q22-23 [32] and has two identified isoforms, $P G R-A$ and $P G R-B$ [33,34]. Progesterone downregulates the production of the inflammatory chemokine IL- 8 at the transcriptional level [35]. The polymorphism (+331G/A), identified by our group [36], creates a novel transcription start site that increases transcriptional activity and alters the PGR isoform ratio. The anti-inflammatory role of the progesterone receptor is mediated by $P G R-A$; however, in the presence of the variant (isoform $\mathrm{A}$ ) there is overproduction of the $P G R-B$ isoform [36].

The aromatase gene (CYP19) encodes aromatase, which catalyzes the aromatization of the androgens androstenedione and testosterone to estrone and estradiol, respectively. Aromatase has been found in synoviocytes [37]. Data from Cutolo and colleagues suggest an accelerated peripheral metabolic conversion of upstream androgen precursors to $17 \beta$-estradiol occurs in RA [3], perhaps via inflammatory cytokines that markedly stimulate aromatase activity in peripheral tissues [38,39]. Moreover, genetic variants in CYP19 have been shown to influence endogenous estrogen levels [40].

The overall goal of the present study is to define the contribution of sex-steroid hormone levels measured in plasma samples collected prior to the onset of RA, and the role of genetic variants in hormones in the steroid pathway in RA etiology. We aimed specifically to assess the association between plasma hormone levels for total testosterone, free testosterone, and DHEAS, as well as genetic polymorphisms in the androgen receptor $(A R)$, estrogen receptor 2 (ESR2), progesterone receptor (PGR), CYP19 and risk of RA in women. The study 
pools data and analysis of prospective collected blood samples from several large female cohorts, the Nurses' Health Study (NHS), the NHS II, and the Women's Health Study (WHS).

\section{Materials and methods Study population}

The NHS is a prospective cohort of 121,700 female nurses, aged 30 to 55 years in 1976. From 1989 to 1990, 32,826 (27\%) NHS participants aged 43 to 70 years provided blood samples for future studies. Further, among women who did not give blood in 1989 to $1990,33,040$ provided buccal cell samples (27\% of NHS) for a total of 65,866 DNA samples $(54 \%$ of the cohort).

The NHS II is a similar prospective cohort, established in 1989 , with 116,609 female nurses aged 25 to 42 years. Between 1996 and 1999, 29,611 (25\%) NHS II cohort members, aged 32 to 52 at that time, also agreed to provide blood samples for future studies. For the NHS cohorts, blood samples were collected in heparinized tubes and were sent by overnight courier in chilled containers.

The WHS was a randomized, double-blind, placebo-controlled trial designed to evaluate the benefits and risks of lowdose aspirin and vitamin $E$ in the primary prevention of cardiovascular disease and cancer among 39,876 female health professionals, aged 45 years and older, conducted between 1992 and 2004 [41-43]. Following the end of the trial, women who were willing to continue participated in an observational follow-up study. From 1992 through 1995, 28,345 women in the WHS provided blood samples in ethylenediamine tetraacetic acid tubes. On receipt, the blood samples were centrifuged, aliquoted into plasma, red blood cells, and buffy coat fractions, and stored in the vapor phase of liquid nitrogen freezers since collection.

All women in these cohorts completed an initial questionnaire regarding diseases, lifestyle, and health practices, and have been followed biennially in the NHS cohorts and annually in the WHS cohort by questionnaire to update exposures and disease diagnoses. All subjects provided informed consent. All aspects of this study were approved by the Partners' HealthCare Institutional Review Board.

\section{Identification of rheumatoid arthritis}

As previously described [44], we confirmed self-reports of RA based on the presence of RA symptoms on a connective tissue disease screening questionnaire [45] and based on medical record review for American College of Rheumatology (ACR) classification criteria for RA [46]. Subjects with four of the seven ACR criteria documented in the medical record were considered to have definite RA. For this nested casecontrol study, we also included a small number of subjects ( $\mathrm{n}$ $=14$ ) with agreement by two rheumatologists on the diagno- sis of RA who had three documented ACR criteria for RA and a diagnosis of RA by their physician.

\section{Population for analysis}

For both cases and controls, we excluded women who reported any cancer (except nonmelanoma skin cancer) at baseline or during follow-up, as cancer and its treatment can affect biomarker levels. In the NHS/NHS II, each case with confirmed incident or prevalent RA with buccal samples was matched on year of birth, race/ethnicity, menopausal status, and postmenopausal hormone use to a single healthy woman in the same cohort without RA. In the WHS, we matched each case to three controls on the same factors. For plasma hormone assays and DNA from buffy coat samples, three controls for each confirmed incident RA case in the NHS cohorts were randomly chosen from subjects with stored blood, matching on the same factors plus time of day and fasting status at blood draw. For premenopausal women in NHS II, we also matched on timing of blood sample in the menstrual cycle. To minimize potential population stratification, we limited the analyses to Caucasians for genetic analyses.

\section{Laboratory assays}

The laboratories selected for this study had high assay precision. The laboratories underwent rigorous pilot testing with blinded aliquots from NHS specimens. The laboratory staff were blinded to the case-control status in study samples. Samples were labeled by number only, and matched casecontrol pairs were handled together identically, shipped in the same batch, and assayed in the same run. The order within each case-control pair was random. Aliquots from pooled quality-control specimens, indistinguishable from study specimens, were interspersed randomly among case-control samples to monitor quality control.

Total testosterone was assayed by specific radioimmunoassay with a solvent extraction step before celite column chromatography [47] at Quest Laboratory, San Juan Capistrano, California. Performance of this assay at Quest Laboratory has been extensively tested in prior NHS study samples with hormone stability studies, test-retest studies, testing duplicate samples, and embedding samples with known values within studies. DHEAS was measured by radioimmunoassay (Diagnostic Systems Laboratories, Webster, TX, USA) at Children's Hospital, Rifai Laboratory (Boston, MA, USA). Sex hormone binding globulin (SHBG) was assayed using a fully automated system (Immulite; DPC, Inc., Los Angeles, CA, USA) at the Reproductive Endocrinology Laboratory at Massachusetts General Hospital, using a solid-phase two-site chemiluminescent enzyme immunometric assay. SHBG levels were used to calculate free testosterone levels [48].

The interassay coefficient of variations for quality-control samples were $14 \%$ for testosterone, $13 \%$ for SHBG, and $4 \%$ for DHEAS. Hormone assays were performed in the NHS cohorts 
but were not performed in the WHS cohort due to nonsignificant findings in the NHS.

\section{DNA extraction}

DNA was extracted from buffy coats or from buccal cell samples (collected by mouthwash swish and spit procedures) and processed via the OIAmp ${ }^{\text {TM }}$ (QIAGEN Inc., Chatsworth, CA, USA) 96-spin blood kit protocol. All genomic DNA samples had an aliquot put through a whole-genome amplification protocol using the GenomPhi DNA amplification kit (GE Healthcare, Piscataway, NJ, USA) to yield high-quality DNA sufficient for SNP genotyping.

\section{SNP genotyping}

DNA was genotyped using Taqman SNP allelic discrimination on the $\mathrm{ABI} 7900 \mathrm{HT}$ using published primers. We used data from the National Cancer Institute Breast and Prostate Cancer Cohort consortium or from the Multi-Ethnic Cohort to select haplotype tagging SNPs for our study [49-51]. SNPs were selected based on resequencing the coding exons of $A R$, ESR2, and CYP19 in a panel of 95 women from the Multi-Ethnic Cohort (19 each from African Americans, Latinos, Japanese, Americans, Native Hawaiians and Whites), with invasive, non-localized breast cancer. SNPs with minor allele frequency $>5 \%$ overall or $>1 \%$ in any one ethnic group were selected from this resequencing as well as those available in the National Center for Biotechnology Information database of single nucleotide polymorphisms [52] from the nonsequenced areas to be used to select haplotype tagging SNPs. The linkage disequilibrium structure was determined by genotyping SNPs among a reference panel of 349 women from Multi-Ethnic Cohort populations (including 70 Whites). Haplotype frequency estimates were constructed from the genotype data for Whites using the expectation-maximization algorithm to select tag SNPs that maximize prediction of common haplotypes (at $R^{2} \mathrm{H} \geq 0.7$, a measure of correlation between SNPs genotyped and the haplotypes they describe).

We selected six haplotype-tag single nucleotide polymorphisms (htSNPs) that have been identified to capture the genetic variation in the $A R$ gene in Caucasians [49] (rs962458, rs6152, rs1204038, rs2361634, rs1337080, and rs1337082), in three haplotype blocks, and considered these as an extended haplotype block [53]. The htSNPs provide a minimum $R^{2}{ }_{\mathrm{H}}$ of 0.77 to describe the haplotype diversity among Japanese, Whites, and Latinas from the Multi-Ethnic Cohort selection panel [49]. Genotyping for the AR CAG repeat polymorphism was performed as previously described [53]. We selected five htSNPs that have been identified to capture the genetic variation in the ESR2 gene in Caucasians [50] (rs3020450, rs1256031, rs1256049, G1730A, and rs944459). The selected htSNPs have a minor allele frequency of $5 \%$ or more and $R^{2} \mathrm{H}>0.7$. Three haplotype blocks span the ESR2 locus and are highly correlated $(r>0.95)$, allowing the analysis of the htSNPs as one block. Based on a report from the Multi-Ethnic Cohort on CYP19 haplotype structure and breast cancer risk, we selected 20 SNPs tagging four haplotype blocks, and $R^{2}{ }_{H}>0.7$ for association with RA risk [40]. These htSNPs were genotyped in HapMap CEU trios to permit an assessment of coverage in relation to the HapMap database (phase II, October 2005) and were estimated to predict $70 \%$ of all common SNPs genotyped in the HapMap CEU population across the four linkage disequilibrium blocks. The variants selected for $P G R$ were based on functional studies performed by co-investigator IDV $[36,54,55]$ rather than a haplotype tagging method. Nonetheless these SNPs captured $90 \%$ of variation in the NHS samples, a predominantly Caucasian population $[36,54,55]$.

\section{Covariate information}

Age was updated in each cycle. Reproductive covariates were chosen based on our past findings of associations between reproductive factors and the risk of developing RA in the NHS [56]. Data on pack-years of smoking (product of years of smoking and packs of cigarettes per day), parity, total duration of breastfeeding (not available in the WHS), age at menarche, menopausal status and postmenopausal hormone use were selected from the questionnaire cycle prior to the date of RA diagnosis (or index date in control individuals).

\section{Statistical analyses}

For analysis of characteristics of cases and controls, we calculated means with standard deviation for continuous variables stratified by cohort. For categorical covariates, we calculated frequencies and percentages. SAS version 9.1.3 software (SAS Institute, Cary, NC, USA) was used for all analyses.

\section{Analyses of hormonal factors}

We calculated means with standard deviation and medians with range for total testosterone, calculated free testosterone and DHEAS. Threshold values for the quartiles for each hormone were created using the distribution in control individuals. We conducted conditional logistic regression models, conditioned on the matching factors, and adjusted for potential confounders including cigarette smoking and reproductive factors assessed prior to diagnosis of RA for total testosterone, calculated free testosterone and DHEAS, comparing quartiles of continuous hormone levels to estimate relative risks and 95\% confidence intervals of RA in the NHS. We repeated the analyses stratified by menopausal status, and by seropositive status.

\section{Analyses of gene-hormone associations}

Analysis of covariance models were used to evaluate the association of the six $A R$ htSNPs and AR CAG repeat length with mean plasma hormone levels adjusting for potential confounders, among 89 control samples with both genetic and hormone information in the two NHS blood cohorts. For the total testosterone and calculated free testosterone models, we 
adjusted for age, body mass index, menopausal status, hormone use and cigarette smoking (never, former, current $<15$ cigarettes per day and current $\geq 15$ cigarettes per day). For DHEAS models, we adjusted for the same covariates as well as the time of day of blood draw.

\section{Analyses of genetic factors}

We verified Hardy-Weinberg equilibrium for each of the genotypes among control individuals in each of the datasets (NHS blood, NHS cheek cells, NHS II blood, WHS blood). We employed conditional logistic regression analyses, conditioned on matching factors, and adjusted for potential confounders, including cigarette smoking and reproductive factors assessed prior to diagnosis of RA. All analyses were first conducted separately in each cohort and then on data pooled from the three cohorts. As the $P$ value for heterogeneity was not significant for the AR, ESR2, PGR, or CYP19 genotypes, we also meta-analytically pooled results from the two cohorts using a DerSimonian and Laird random-effects model [57]. In addition, analyses were repeated stratifying by rheumatoid factor status of the RA cases.

We determined common haplotypes in cases and controls using PROC HAPLOTYPE in SAS Genetics. The haplotype dosage estimate was computed using individual genotype data and haplotype frequency estimates from the entire dataset. We pooled rare haplotypes ( $<5 \%$ frequency) into a single category. Conditional logistic regression analyses conditioned on matching factors, and adjusted for potential confounders, were performed for block-specific haplotype associations with $\mathrm{RA}$ risk. A likelihood ratio test was performed to test for global haplotype associations, using the most common haplotype as the reference category.

Cochran-Mantel-Haenszel chi-square tests were conducted to evaluate case-control differences in the frequency of the $A R$ CAG alleles using multiple cutoff points. In most analyses, we used the cutoff point $(C A G)_{n} \geq 22$ repeats, which has been most frequently used in the literature. We used conditional logistic regression adjusted for potential confounders to assess the increase in log odds of RA per unit increase in CAG repeat, and also examined various cutoff points for repeat length in similar models.

\section{Analyses of gene-smoking interactions}

We assessed gene-smoking interactions using a multiplicative interaction variable (for example, genotype $\times$ smoking) in the conditional logistic regression models. The significance of the interaction was determined using the Wald chi-square test of the interaction variable. In the combined NHS-NHS II nested case-control study dataset, we assessed for interactions between the presence of each polymorphism and cigarette smoking dichotomized as $\leq 10$ or $>10$ pack-years of smoking to account for heavy smoking, as this is the threshold we previously identified to be associated with increased risk of
RA [44]. In the WHS cohort we assessed for interaction between polymorphisms and ever/never smoking, as packyear information was not available.

\section{Results}

Genetic analyses were limited to Caucasian matched pairs to minimize the potential for population stratification. In the NHS cohorts, we confirmed 449 Caucasian RA cases with available DNA and 132 cases with available plasma samples collected prior to first RA symptoms (preclinical RA). In chart reviews, 433 cases had at least four ACR criteria, 14 cases had at least three ACR criteria, and all cases had two rheumatologist reviewers' consensus on RA diagnosis. In the WHS cohort, we confirmed 72 Caucasian RA cases with stored samples. Fifty-eight percent of RA cases in both the NHS and WHS cohorts were rheumatoid factor positive by chart review. In the 132 pre-RA cases with plasma, the mean time between blood draw and RA symptoms was 6.8 years (range $=0$ to 14.2 years). The distribution of potential confounders was similar among cases and controls (Table 1). Among RA cases, 179 (67\%) were postmenopausal in the NHS cohort and 39 (54\%) were postmenopausal in the WHS cohort at blood draw.

\section{Plasma androgens in cases compared with controls in the NHS}

Comparing the lowest quartile with the highest quartile of total testosterone or calculated free testosterone there were no significant associations with RA risk in univariate analysis or after adjusting for confounders (Table 2). For example, the top quartile of calculated free testosterone level was associated with a relative risk of 1.7 ( $95 \%$ confidence interval $=0.8$ to 3.5 ). Similarly for DHEAS, there was no evidence of increased RA risk with low DHEAS in either univariate or multivariable analysis. Stratified analyses among premenopausal women and postmenopausal women and among seropositive or seronegative RA had similar results (data not shown).

\section{Androgen receptor polymorphisms and hormone levels in the NHS}

There were modest associations between several AR SNPs and plasma hormone levels among control samples (Table 3 ). The variant genotypes for rs962458, rs6152, rs1204038 and rs1337080 were associated with higher plasma calculated free testosterone levels $(P=0.03, P=0.03, P=0.05$ and $P$ $=0.03$, respectively) and rs6152 was associated with total testosterone $(P=0.04)$. We found no significant association between the length of the AR CAG repeat and hormone levels among 89 control samples (data not shown).

\section{Androgen receptor polymorphisms in the NHS and the WHS}

Using a dominant model there was no association with RA for any of the six htSNPs in the NHS, in the WHS, and in the pooled sample with 522 cases and 662 controls in adjusted analyses (see Table S1 in Additional data file 1). In pooled 
Characteristics of rheumatoid arthritis cases and matched controls in the NHS and WHS

\begin{tabular}{|c|c|c|c|c|}
\hline & \multicolumn{2}{|c|}{$\begin{array}{c}\text { NHS } \\
\text { (449 cases/449 controls) }\end{array}$} & \multicolumn{2}{|c|}{$\begin{array}{c}\text { WHS } \\
\text { (72 cases/202 controls) }\end{array}$} \\
\hline & RA cases & Controls & RA cases & Controls \\
\hline \multicolumn{5}{|l|}{ Matching factors } \\
\hline Age at blood draw & $55 \pm 8$ & $55 \pm 8$ & $55 \pm 8$ & $55 \pm 8$ \\
\hline Postmenopausala & $179(67 \%)$ & $179(67 \%)$ & $39(54 \%)$ & $109(54 \%)$ \\
\hline Current postmenopausal hormone use & $92(34 \%)$ & $93(35 \%)$ & $37(51 \%)$ & $104(51 \%)$ \\
\hline \multicolumn{5}{|l|}{ Other characteristics } \\
\hline Ever cigarette smokers & $272(61 \%)$ & $252(56 \%)$ & $46(64 \%)$ & $106(52 \%)$ \\
\hline Pack-years among smokers & $23 \pm 16$ & $23 \pm 20$ & - & - \\
\hline Parous & $411(92 \%)$ & $420(94 \%)$ & $62(86 \%)$ & $180(89 \%)$ \\
\hline Breastfed babies $\geq 12$ months total ${ }^{b}$ & $67(15 \%)$ & $81(18 \%)$ & - & - \\
\hline Age at menarche $<12$ years & $107(24 \%)$ & $96(22 \%)$ & $18(25 \%)$ & $47(23 \%)$ \\
\hline Irregular menstrual cycles & $66(15 \%)$ & $61(14 \%)$ & - & - \\
\hline Body mass index $\left(\mathrm{kg} / \mathrm{m}^{2}\right)$ & $26 \pm 5$ & $26 \pm 5$ & $26 \pm 6$ & $26 \pm 5$ \\
\hline \multicolumn{5}{|l|}{ Rheumatoid arthritis characteristics } \\
\hline Age at diagnosis & $55 \pm 10$ & & $61 \pm 8$ & \\
\hline Rheumatoid factor positive & $260(58 \%)$ & & $42(58 \%)$ & \\
\hline Cyclic citrullinated antibody positive ${ }^{c}$ & $73(55 \%)$ & & - & \\
\hline Rheumatoid nodules & $59(13 \%)$ & & $9(13 \%)$ & \\
\hline Radiographic changes & $137(31 \%)$ & & $15(21 \%)$ & \\
\hline \multicolumn{5}{|l|}{ Hormone levels ${ }^{d}$} \\
\hline Free testosterone $(\mathrm{pg} / \mathrm{ml})$ & $0.06(0.03)$ & $0.06(0.03)$ & & \\
\hline Free testosterone $(\mathrm{pg} / \mathrm{ml})$ & $0.06(0.05$ to 0.08$)$ & $0.06(0.04$ to 0.08$)$ & & \\
\hline Total testosterone $(\mathrm{pg} / \mathrm{ml})$ & $22.0 \pm 10.0$ & $21.7 \pm 11.1$ & & \\
\hline Total testosterone $(\mathrm{pg} / \mathrm{ml})$ & $22.0(16.0$ to 31.0$)$ & $21.0(16.0$ to 29.0$)$ & & \\
\hline DHEAS (pg/ml) & $91.1 \pm 68.9$ & $87.5 \pm 59.0$ & & \\
\hline DHEAS (pg/ml) & 72.1 (38.5 to 113.9$)$ & $69.0(46.0$ to 116.4$)$ & & \\
\hline
\end{tabular}

Data presented as mean \pm standard deviation, $n$ (\%) or median (25th to 75th percentile). aPercentage is calculated among postmenopausal women or parous women, with unknown/missing group excluded. For the rest of the variables, percentage was calculated with missing category included. bCalculated among parous women in the Nurses' Health Study (NHS), data not available in the Women's Health Study (WHS). ${ }^{\circ} \mathrm{Cyclic}$ citrullinated peptide antibodies tested in 132 preclinical rheumatoid arthritis (RA) samples. dMeasured in NHS samples for free and total testosterone and dehydroepiandrosterone sulfate (DHEAS) $(n=132$ rheumatoid arthritis cases, $n=396$ controls).

analyses, with stratification into rheumatoid factor-positive and rheumatoid factor-negative RA, the odds ratios were modestly elevated for rheumatoid factor-positive RA but remained nonsignificant (see Table S2 in Additional data file 1). Haplotype analysis had similar null results (Table 4). There was no evidence for any interaction between the six htSNPs in the androgen receptor and cigarette smoking classified as never/ever smoked in the combined analysis, or classified as never $/ \leq 10$ pack-years of smoking versus $>10$ pack-years of smoking in the NHS analysis (data not shown). We found no significant association between the length of the AR CAG repeat and RA risk (data not shown).

\section{ESR2, PGR, and CYP19 polymorphisms in the NHS and the WHS}

For ESR2, PGR and CYP19, none of the individual htSNPs were significantly associated with RA. A single haplotype in ESR2 and a single haplotype in PGR were associated with RA; however, the global tests for haplotype association were not significant for ESR2 $(P=0.06)$ and for $P G R(P=0.21)$ 


\begin{tabular}{|c|c|c|c|c|c|c|}
\hline & Quartile 1 & Quartile 2 & Quartile 3 & Quartile 4 & $P$ trend $^{\mathrm{a}}$ & $P$ continuous $^{\mathrm{b}}$ \\
\hline \multicolumn{7}{|l|}{ Free testosterone } \\
\hline Median (controls) & 0.028 & 0.046 & 0.061 & 0.085 & & \\
\hline Cases/controls & $25 / 98$ & $36 / 98$ & $37 / 98$ & $33 / 98$ & & \\
\hline Unadjustedc & 1.0 & $1.6(0.8$ to 2.9$)$ & 1.7 (0.9 to 3.2$)$ & 1.5 (0.8 to 3.0$)$ & 0.36 & 0.51 \\
\hline Adjustedd & 1.0 & 1.5 (0.8 to 2.8$)$ & $1.6(0.8$ to 3.3$)$ & 1.7 (0.8 to 3.5$)$ & 0.24 & 0.44 \\
\hline \multicolumn{7}{|l|}{ Total testosterone } \\
\hline Median (controls) & 11.0 & 18.0 & 23.0 & 34.0 & & \\
\hline Cases/controls & $32 / 104$ & $33 / 103$ & $31 / 96$ & $36 / 92$ & & \\
\hline Unadjustedc & 1.0 & $1.1(0.6$ to 1.9$)$ & $1.1(0.6$ to 2.1$)$ & $1.4(0.7$ to 2.5$)$ & 0.32 & 0.75 \\
\hline Adjusted $^{d}$ & 1.0 & 1.1 (0.6 to 2.0$)$ & $1.2(0.6$ to 2.4$)$ & 1.5 (0.8 to 2.9$)$ & 0.20 & 0.52 \\
\hline \multicolumn{7}{|c|}{ Dehydroepiandrosterone sulfate } \\
\hline Median (controls) & 30.58 & 56.16 & 93.10 & 158.20 & & \\
\hline Cases/controls & $40 / 98$ & $20 / 98$ & $37 / 98$ & $34 / 98$ & & \\
\hline Unadjustedc & 1.0 & 0.5 (0.3 to 0.9$)$ & 0.9 (0.5 to 1.6$)$ & 0.8 (0.5 to 1.5$)$ & 0.85 & 0.51 \\
\hline Adjustedd & 1.0 & $0.5(0.3$ to 1.0$)$ & $0.9(0.5$ to 1.5$)$ & $0.7(0.4$ to 1.4$)$ & 0.66 & 0.71 \\
\hline
\end{tabular}

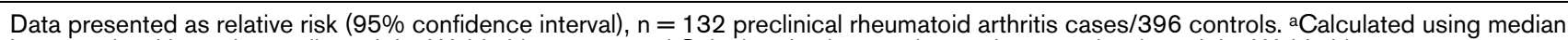
hormone level in each quartile and the Wald chi-square test. bCalculated using continuous hormone levels and the Wald chi-square test.

${ }^{c}$ Conditional logistic regression conditioned on strata defined by matched factors. ${ }^{d}$ Conditional logistic regression conditioned on matching factors, adjusted for body mass index (continuous), cigarette smoking (never, past, current smoker $<15$ cigarettes per day, current smoker $\geq 15$ cigarettes per day), age at menarche, menstrual regularity, parity, breastfeeding.

(Table 4). There was no association for haplotypes in CYP19, blocks 2, 3, or 4 (data not shown). There were four haplotypes in CYP19, block 1 that were modestly associated with RA in adjusted analyses (Table 4), with a significant global test for haplotype association $(P=0.02)$. None of these findings were significant after adjustment for multiple comparisons.

\section{Discussion}

We found no evidence that women with pre-RA have lower plasma androgen levels than matched control individuals in this nested case-control study that included 132 incident RA cases with plasma blood samples collected prior to disease onset and 396 controls. This finding is consistent with a casecontrol study nested in a Finnish cohort of 19,072 subjects, which demonstrated no differences in concentration of total testosterone and DHEAS measured in stored serum specimens collected up to 16 years prior to diagnosis between 116 pre-RA cases (32 men, 84 women) and controls [18]. Serum SHBG was not measured in that study, and therefore the biologically active form - free testosterone - could not be determined. In contrast, a smaller study demonstrated low DHEAS among 11 premenopausal pre-RA women compared with control individuals, with levels measured 7 to 18 years prior to RA onset. In stratified analyses, however, we could not confirm an association between DHEAS and RA in premenopausal women. The observed androgen deficiency reported in the lit- erature in existing RA [6-10] is most probably a consequence of the disease, and not causal.

In a small sample of 89 controls with both genotype and plasma hormone results, we demonstrated that four of the $A R$ SNPs were associated with higher free testosterone levels suggesting that these polymorphisms may have functional effects, although the sample size is small. We found no evidence, however, of polymorphisms in the AR gene being associated with RA risk in unadjusted analyses or after adjustment for potential confounders. Similarly, none of the individual polymorphisms in ESR2, PGR, and CYP19 or in the AR CAG repeat was associated with RA risk. There was some modest evidence for haplotype associations in ESR2, PGR and CYP19, block 1; however, none of these results were significant after adjustment for multiple comparisons.

Studies regarding repeat polymorphisms in AR suggest associations between CAG repeat length and clinical features of RA but no association with RA susceptibility [58-60]. Associations regarding ESR2 repeat polymorphisms and clinical features of RA have been reported [61,62]. An association between CYP19 and RA was reported in a linkage study [63]. No case-control association studies for SNPs or haplotypes, however, have been reported for $A R, E S R 2, P G R$, and CYP19. None of the published genome-wide association 
Table 3

Association of $A R$ haplotype-tag polymorphisms and plasma hormone levels in the Nurses' Health Studies

\begin{tabular}{|c|c|c|c|}
\hline$A R$ SNP & Dehydroepiandrosterone sulfate ${ }^{a}$ & Total testosterone ${ }^{b}$ & Free testosterone ${ }^{c}$ \\
\hline \multicolumn{4}{|l|}{ rs962458 } \\
\hline $\mathrm{CC}$ & $96.6 \pm 12.6$ & $23.2 \pm 1.4$ & $0.062 \pm 0.003$ \\
\hline $\mathrm{CT} / \mathrm{TT}$ & $98.5 \pm 19.2$ & $30.2 \pm 3.4$ & $0.081 \pm 0.008$ \\
\hline$P$ value & 0.91 & 0.06 & 0.03 \\
\hline \multicolumn{4}{|l|}{ rs6152 } \\
\hline AA & $84.7 \pm 14.0$ & $22.5 \pm 1.5$ & $0.060 \pm 0.004$ \\
\hline AG/GG & $109.8 \pm 14.4$ & $28.8 \pm 2.6$ & $0.076 \pm 0.006$ \\
\hline$P$ value & 0.07 & 0.04 & 0.03 \\
\hline \multicolumn{4}{|l|}{ rs1204038 } \\
\hline $\mathrm{TT}$ & $86.7 \pm 14.3$ & $22.1 \pm 1.5$ & $0.059 \pm 0.004$ \\
\hline $\mathrm{TC} / \mathrm{CC}$ & $104.9 \pm 13.8$ & $27.4 \pm 2.2$ & $0.073 \pm 0.006$ \\
\hline$P$ value & 0.17 & 0.06 & 0.05 \\
\hline \multicolumn{4}{|l|}{ rs2361634 } \\
\hline GG & $97.1 \pm 12.5$ & $24.2 \pm 1.4$ & $0.064 \pm 0.003$ \\
\hline $\mathrm{GA} / \mathrm{AA}$ & $92.1 \pm 19.1$ & $24.3 \pm 3.4$ & $0.067 \pm 0.008$ \\
\hline$P$ value & 0.76 & 0.96 & 0.71 \\
\hline \multicolumn{4}{|l|}{ rs1337080 } \\
\hline GG & $96.4 \pm 12.5$ & $23.2 \pm 1.4$ & $0.061 \pm 0.003$ \\
\hline GA/AA & $98.6 \pm 19.1$ & $30.2 \pm 3.4$ & $0.080 \pm 0.008$ \\
\hline$P$ value & 0.89 & 0.06 & 0.03 \\
\hline \multicolumn{4}{|l|}{ rs1337082 } \\
\hline GG & $87.1 \pm 14.4$ & $22.7 \pm 1.8$ & $0.060 \pm 0.004$ \\
\hline GA/AA & $101.8 \pm 13.2$ & $25.4 \pm 1.9$ & $0.068 \pm 0.005$ \\
\hline$P$ value & 0.22 & 0.32 & 0.20 \\
\hline
\end{tabular}

Androgen receptor gene $(A R)$ association in 89 controls from the Nurses' Health Studies. Data presented as mean \pm standard deviation. aAnalysis of covariance adjusted for age (continuous), body mass index (continuous), menopausal status and postmenopausal hormone use, cigarette smoking (never, past, current smoker $<15$ cigarettes per day, current smoker $\geq 15$ cigarettes per day) and time of day of blood draw. ${ }^{b}$ Analysis of covariance adjusted for age (continuous), body mass index (continuous), menopausal status and postmenopausal hormone use, and cigarette smoking (never, past, current smoker $<15$ cigarettes per day, current smoker $\geq 15$ cigarettes per day). ${ }^{\circ}$ Analysis of covariance adjusted for age (continuous), body mass index (continuous), menopausal status and postmenopausal hormone use, and cigarette smoking (never, past, current smoker $<15$ cigarettes per day, current smoker $\geq 15$ cigarettes per day).

studies have reported significant findings for these genes either $[64,65]$.

The prospective design of these cohorts allowed us to study plasma androgen levels up to 14 years prior to RA onset and to adjust for a number of potential confounders such as cigarette smoking and reproductive factors. There were several limitations to the study design, however, including the small number of incident RA cases after the blood collection, which limited the power to detect hormone associations, and the lack of repeated blood samples at multiple timepoints prior to RA. Data from the NHS, however, indicate that a single sample reflects long-term hormone levels reasonably well. For instance, postmenopausal hormone levels measured three times over a 3-year period in 79 women from the NHS reliably categorized average levels with intraclass correlations of 0.88 for testosterone, 0.88 for DHEAS, and 0.92 for SHBG [66]. We studied plasma androgens rather than local androgen levels such as synovial fluid levels that may be more indicative of an altered estrogen-androgen balance in the pathophysiology of RA [14]. With 132 cases and 396 controls we have $80 \%$ power to detect an odds ratio of 0.38 for the top quartile as compared with the lowest quartile. For the genetic analyses, we limited the analysis to women with self-reported Caucasian ancestry to minimize population stratification, and other studies have reported little stratification in this cohort [67]. With 
Associations of AR haplotypes, ESR2 haplotypes, PGR haplotypes, CYP19, block 1 haplotypes and RA risk

\begin{tabular}{|c|c|c|c|c|}
\hline & Cases (\%) & Controls (\%) & Odds ratio $(95 \%$ confidence interval)a & Odds ratio (95\% confidence interval)b \\
\hline \multicolumn{5}{|c|}{$A R$ long-range haplotypes ${ }^{c}$} \\
\hline $0-0-0-0-0-0$ & 71.2 & 69.7 & 1.00 reference & 1.00 reference \\
\hline $0-1-1-0-0-1$ & 8.1 & 8.1 & $0.98(0.72$ to 1.33$)$ & 0.99 (0.72 to 1.36$)$ \\
\hline $0-0-0-1-0-0$ & 6.7 & 8.0 & $0.86(0.62$ to 1.19$)$ & $0.82(0.58$ to 1.14$)$ \\
\hline $1-1-1-0-1-1$ & 6.4 & 5.3 & $1.19(0.82$ to 1.71$)$ & $1.29(0.88$ to 1.88$)$ \\
\hline $0-0-0-0-0-1$ & 4.7 & 6.1 & 0.73 (0.50 to 1.07$)$ & $0.76(0.51$ to 1.12$)$ \\
\hline \multicolumn{5}{|c|}{ ESR2 haplotypes ${ }^{d}$} \\
\hline $0-1-0-0-0$ & 42.4 & 46.8 & 1.00 & 1.00 \\
\hline $1-0-0-1-0$ & 27.2 & 24.7 & $1.16(0.95$ to 1.42$)$ & $1.15(0.94$ to 1.41$)$ \\
\hline $0-0-0-0-0$ & 10.9 & 8.3 & $1.47(1.07$ to 2.01$)$ & 1.44 (1.05 to 1.98$)$ \\
\hline $0-0-0-1-0$ & 9.1 & 9.6 & 0.99 (0.71 to 1.38$)$ & 0.91 (0.65 to 1.28$)$ \\
\hline \multicolumn{5}{|c|}{$P G R$ haplotypes ${ }^{\mathrm{e}}$} \\
\hline $0-0-0-0$ & 41.2 & 37.5 & 1.00 & 1.00 \\
\hline $0-0-1-0$ & 34.4 & 34.2 & $0.93(0.75$ to 1.14$)$ & $0.92(0.75$ to 1.14$)$ \\
\hline $0-0-0-1$ & 13.1 & 16.3 & 0.72 (0.55 to 0.94$)$ & 0.73 (0.56 to 0.95$)$ \\
\hline $1-0-0-0$ & 6.3 & 7.4 & 0.75 (0.53 to 1.06$)$ & 0.75 (0.53 to 1.07$)$ \\
\hline \multicolumn{5}{|c|}{ CYP19, block 1 haplotypes ${ }^{f}$} \\
\hline $0-0-1-0-0-0$ & 39.2 & 31.2 & 1.00 & 1.00 \\
\hline $0-0-0-1-1-0$ & 14.0 & 14.4 & 0.68 (0.50 to 0.94$)$ & 0.71 (0.52 to 0.98$)$ \\
\hline $0-0-0-0-1-0$ & 10.4 & 14.4 & 0.81 (0.61 to 1.08$)$ & $0.83(0.62$ to 1.11$)$ \\
\hline $0-0-0-0-0-0$ & 10.3 & 9.6 & 0.69 (0.51 to 0.93$)$ & $0.71(0.52$ to 0.96$)$ \\
\hline $1-1-0-0-1-1$ & 5.5 & 6.5 & 0.58 (0.38 to 0.88$)$ & 0.58 (0.38 to 0.88$)$ \\
\hline
\end{tabular}

RA, rheumatoid arthritis. aConditional logistic regression, conditioning on matching factors. ${ }^{b}$ Conditional logistic regression, conditioning on matching factors and adjusting for cigarette smoking (never, past, current smoker $<15$ cigarettes per day, current smoker $\geq 15$ cigarettes per day) age at menarche and parity. cAndrogen receptor gene $(A R)$ haplotype-tagged SNPs: rs962458-rs6152-rs1204038-rs2361634-rs1337080rs1337082. dEstrogen receptor 2 gene (ESR2) haplotype-tagged SNPs: rs3020450-rs1256031-rs1256049-rs4986938-rs944459.

eProgesterone receptor gene (PGR) haplotype-tagged SNPs: rs518162-rs10895068-rs1379130-rs1042839. ${ }^{\mathrm{A} A r o m a t a s e}$ gene (CYP19) block 1 haplotype-tagged SNPs: rs2446405-rs2445765-rs2470144-rs2445762-rs1004984-rs1902584; global haplotype association, $P=0.02$.

521 cases and 651 controls, we had $86 \%$ power to detect an odds ratio of 1.5 for minor allele frequencies of $15 \%$, but only $27 \%$ power to detect odds ratios of 1.2 . The power to detect modest odds ratios, such as those demonstrated in recent genome-wide association studies in RA [68-70], was therefore quite limited.

\section{Conclusions}

Although the possibility of a biologic relationship between $A R$, androgen levels, and RA risk is intriguing, our findings do not suggest that $A R$ is related to RA risk in women. We do not show any significant associations for other hormone-related genes, ESR2, PGR and CYP19 and RA risk after adjustment for multiple comparisons. Steroid hormone levels measured at a single timepoint from 0 to 14 years prior to RA onset were not associated with RA risk in the present study. In conclusion, among women in the NHS, NHS II and WHS, neither hormone receptor genes nor plasma steroid hormone levels are associated with RA risk.

\section{Competing interests}

PAF receives salary from Genzyme Corporation. Genzyme Corporation will not in any way gain or lose financially from the publication of the present manuscript, either now or in the future. Genzyme is not financing this manuscript. PAF holds Genzyme Corporation stocks and shares that will not in any way gain or lose financially from the publication of this manuscript, either now or in the future.

\section{Authors' contributions}

EWK participated in the study design, data acquisition, analysis and interpretation of data, and manuscript preparation. 
LBC participated in the study design, statistical analysis and interpretation of data, and manuscript preparation. MM participated in the study design, statistical analysis and interpretation of the data. S-CC participated in statistical analysis. BTK participated in statistical analysis and manuscript preparation. $\mathrm{KHC}$ participated in data acquisition, interpretation of data, and manuscript preparation. PAF participated in the study design and interpretation of the data. ST participated in the study design, statistical analysis and interpretation of data, and manuscript preparation. SEH participated in interpretation of the data and manuscript preparation. I-ML participated in the study design and interpretation of the data. JB participated in the study design and interpretation of the data. IDV participated in the study design, interpretation of the data, and manuscript preparation.

\section{Additional files}

The following Additional files are available online:

\section{Additional file 1}

A Word file containing two tables that list the association of htSNPs in the AR gene and RA. Table S1 presents the association of the six htSNPs in the $A R$ gene with RA in the NHS, in the WHS, and in the pooled sample. Table S2 presents the association of the six htSNPs in the $A R$ gene with seropositive RA and seronegative RA in the NHS, in the WHS, and in the pooled sample.

See http://www.biomedcentral.com/content/ supplementary/ar2742-S1.doc

\section{Acknowledgements}

The authors thank the participants in the NHS and the WHS cohorts for their dedication and continued participation in these longitudinal studies, and thank the staff of the NHS and WHS for their assistance with this project. The present work was supported by $\mathrm{NIH}$ grants R01 AR49880, CA87969, HL43851, HL 080467 CA47988, P60 AR047782, K24 AR0524-01 and BIRCWH K12 HD051959 (supported by NIMH, NIAID, NICHD, and OD). KHC is the recipient of an Arthritis Foundation/American College of Rheumatology Arthritis Investigator Award and a Katherine Swan Ginsburg Memorial Award.

\section{References}

1. Linos A, Worthington JW, O'Fallon WM, Kurland LT: The epidemiology of rheumatoid arthritis in Rochester, Minnesota: a study of incidence, prevalence, and mortality. Am J Epidemiol 1980, 111:87-98.

2. Symmons DP, Barrett EM, Bankhead CR, Scott DG, Silman AJ: The incidence of rheumatoid arthritis in the United Kingdom: results from the Norfolk Arthritis Register. $\mathrm{Br} J$ Rheumatol $1994,33: 735-739$.

3. Cutolo M, Capellino S, Sulli A, Serioli B, Secchi ME, Villaggio B, Straub RH: Estrogens and autoimmune diseases. Ann NY Acad Sci 2006, 1089:538-547.

4. Masi AT, Aldag JC, Chatterton RT: Sex hormones and risks of rheumatoid arthritis and developmental or environmental influences. Ann N Y Acad Sci 2006, 1069:223-235.
5. Davidson JM, Chen JJ, Crapo L, Gray GD, Greenleaf WJ, Catania JA: Hormonal changes and sexual function in aging men. $J$ Clin Endocrinol Metab 1983, 57:71-77.

6. Sambrook PN, Eisman JA, Champion GD, Pocock NA: Sex hormone status and osteoporosis in postmenopausal women with rheumatoid arthritis. Arthritis Rheum 1988, 31:973-978.

7. Spector TD, Perry LA, Tubb G, Silman AJ, Huskisson EC: Low free testosterone levels in rheumatoid arthritis. Ann Rheum Dis 1988, 47:65-68.

8. Cutolo M, Balleari E, Giusti M, Monachesi M, Accardo S: Sex hormone status of male patients with rheumatoid arthritis: evidence of low serum concentrations of testosterone at baseline and after human chorionic gonadotropin stimulation. Arthritis Rheum 1988, 31:1314-1317.

9. Gagnerault MC, Touraine P, Savino W, Kelly PA, Dardenne M: Expression of prolactin receptors in murine lymphoid cells in normal and autoimmune situations. J Immunol 1993, 150:5673-5681.

10. Masi AT, Feigenbaum SL, Chatterton RT: Hormonal and pregnancy relationships to rheumatoid arthritis: convergent effects with immunologic and microvascular systems. Semin Arthritis Rheum 1995, 25:1-27.

11. Gordon D, Beastall GH, Thomson JA, Sturrock RD: Prolonged hypogonadism in male patients with rheumatoid arthritis during flares in disease activity. Br J Rheumatol 1988, 27:440-444.

12. Deighton CM, Watson MJ, Walker DJ: Sex hormones in postmenopausal HLA-identical rheumatoid arthritis discordant sibling pairs. I Rheumatol 1992, 19:1663-1667.

13. Cutolo M, Accardo S, Villaggio B, Barone A, Sulli A, Coviello DA, Carabbio C, Felli L, Miceli D, Farruggio R, Carruba G, Castagnetta $\mathrm{L}$ : Androgen and estrogen receptors are present in primary cultures of human synovial macrophages. J Clin Endocrinol Metab 1996, 81:820-827.

14. Castagnetta LA, Carruba G, Granata OM, Stefano R, Miele M, Schmidt M, Cutolo M, Straub RH: Increased estrogen formation and estrogen to androgen ratio in the synovial fluid of patients with rheumatoid arthritis. J Rheumatol 2003, 30:2597-2605.

15. Booji A, Biewenga-Booji CM, Huber-Bruning $\mathrm{O}$, Cornelis $\mathrm{C}$, Jacobs JW, Bijlsma JW: Androgens as adjuvant treatment in postmenopausal female patients with rheumatoid arthritis. Ann Rheum Dis 1996, 55:811-815.

16. Cutolo M, Balleari E, Giusti M, Intra E, Accardo S: Androgen replacement therapy in male patients with rheumatoid arthritis. Arthritis Rheum 1991, 34:1-5.

17. Masi AT, Bijlsma JW, Chikanza IC, Pitzalis C, Cutolo M: Neuroendocrine, immunologic, and microvascular systems interactions in rheumatoid arthritis: physiopathogenetic and therapeutic perspectives [review, 115 refs]. Semin Arthritis Rheum 1999, 29:65-81.

18. Heikkila R, Aho K, Heliovaara M, Knekt $P$, Reunanen A, Aromaa A, Leino A, Palosuo T: Serum androgen-anabolic hormones and the risk of rheumatoid arthritis. Ann Rheum Dis 1998, 57:281-285.

19. Bellido T, Jilka RL, Boyce BF, Girasole G, Broxmeyer H, Dalrymple SA, Murray R, Manolagas SC: Regulation of interleukin-6, osteoclastogenesis, and bone mass by androgens. The role of the androgen receptor. J Clin Invest 1995, 95:2886-2895.

20. Cutolo M, Sulli A, Villaggio B, Seriolo B, Accardo S: Relations between steroid hormones and cytokines in rheumatoid arthritis and systemic lupus erythematosus [review, 67 refs]. Ann Rheum Dis 1998, 57:573-577.

21. Dalal M, Kim S, Voskuhl RR: Testosterone therapy ameliorates experimental autoimmune encephalomyelitis and induces a T helper 2 bias in the autoantigen-specific $T$ lymphocyte response. J Immunol 1997, 159:3-6.

22. Giltay EJ, Fonk JC, von B, Drexhage HA, Schalkwijk C, Gooren LJ: In vivo effects of sex steroids on lymphocyte responsiveness and immunoglobulin levels in humans. J Clin Endocrinol Metab 2000, 85:1648-1657.

23. Morita $Y$, Yamamura M, Nishida $K$, Harada $S$, Okamoto $H$, Inoue $H$, Ohmoto Y, Modlin RL, Makino H: Expression of interleukin-12 in synovial tissue from patients with rheumatoid arthritis. Arthritis Rheum 1998, 41:306-314.

24. Suzuki T, Suzuki N, Engleman EG, Mizushima Y, Sakane T: Low serum levels of dehydroepiandrosterone may cause deficient IL-2 production by lymphocytes in patients with systemic 
lupus erythematosus (SLE). Clin Exp Immunol 1995, 99:251-255.

25. Feldmann M, Brennan FM, Maini RN: Role of cytokines in rheumatoid arthritis [review, 226 refs]. Annu Rev Immunol 1996, 14:397-440.

26. Silman A, Kay A, Brennan P: Timing of pregnancy in relation to the onset of rheumatoid arthritis. Arthritis Rheum 1992, 35:152-155

27. Quigley CA, De Bellis A, Marschke KB, el-Awady MK, Wilson EM, French FS: Androgen receptor defects: historical, clinical, and molecular perspectives. Endocr Rev 1995, 16:271-321.

28. Chamberlain NL, Driver ED, Miesfeld RL: The length and location of CAG trinucleotide repeats in the androgen receptor $\mathrm{N}$-terminal domain affect transactivation function. Nucl Acids Res 1994, 22:3181-3186.

29. Tut TG, Ghadessy FJ, Trifiro MA, Pinsky L, Yong EL: Long polyglutamine tracts in the androgen receptor are associated with reduced trans-activation, impaired sperm production, and male infertility. J Clin Endocrinol Metab 1997, 82:3777-3782.

30. Westberg L, Baghaei F, Rosmond R, Hellstrand M, Landen M, Jansson M, Holm G, Bjorntorp P, Eriksson E: Polymorphisms of the androgen receptor gene and the estrogen receptor beta gene are associated with androgen levels in women. J Clin Endocrinol Metab 2001, 86:2562-2568.

31. Cutolo $M$, Accardo S, Villaggio $B$, Clerico $P$, Bagnasco $M$, Coviello DA, Carruba G, lo Casto M, Castagnetta L: Presence of estrogen-binding sites on macrophage-like synoviocytes and $\mathrm{CD}^{+}$, $\mathrm{CD}^{2} 9^{+}, \mathrm{CD}_{45 \mathrm{RO}^{+} \mathrm{T}} \mathrm{T}$ lymphocytes in normal and rheumatoid synovium. Arthritis Rheum 1993, 36:1087-1097.

32. Rousseau-Merck MF, Misrahi M, Loosfelt H, Milgrom E, Berger R: Localization of the human progesterone receptor gene to chromosome 11q22-q23. Hum Genet 1987, 77:280-282

33. Horwitz KB, Alexander PS: In situ photolinked nuclear progesterone receptors of human breast cancer cells: subunit molecular weights after transformation and translocation. Endocrinology 1983, 113:2195-2201.

34. Wei LL, Miner R: Evidence for the existence of a third progesterone receptor protein in human breast cancer cell line T47D. Cancer Res 1994, 54:340-343.

35. Ito A, Imada K, Sato T, Kubo T, Matsushima K, Mori Y: Suppression of interleukin 8 production by progesterone in rabbit uterine cervix. Biochem J 1994, 301(Pt 1):183-186.

36. De Vivo I, Hankinson SE, Colditz GA, Hunter DJ: The progesterone receptor Val660 $\rightarrow$ Leu polymorphism and breast cancer risk. Breast Cancer Res 2004, 6:R636-R639.

37. Le Bail J, Liagre B, Vergne P, Bertin P, Beneytout J, Habrioux G: Aromatase in synovial cells from postmenopausal women. Steroids 2001, 66:749-757.

38. Macdiarmid F, Wang D, Duncan $\sqcup$, Purohit A, Ghilchick MW, Reed MJ: Stimulation of aromatase activity in breast fibroblasts by tumor necrosis factor alpha. Mol Cell Endocrinol 1994, 106:17-21.

39. Purohit A, Ghilchik MW, Duncan L, Wang DY, Singh A, Walker MM, Reed MJ: Aromatase activity and interleukin-6 production by normal and malignant breast tissues. J Clin Endocrinol Metab 1995, 80:3052-3058.

40. Haiman CA, Stram DO, Pike MC, Kolonel LN, Burtt NP, Altshuler D, Hirschhorn J, Henderson BE: A comprehensive haplotype analysis of CYP19 and breast cancer risk: the Multiethnic Cohort. Hum Mol Genet 2003, 12:2679-2692.

41. Ridker PM, Cook NR, Lee IM, Gordon D, Gaziano JM, Manson JE, Hennekens $\mathrm{CH}$, Buring JE: A randomized trial of low-dose aspirin in the primary prevention of cardiovascular disease in women. N Engl J Med 2005, 352:1293-1304.

42. Lee IM, Cook NR, Gaziano JM, Gordon D, Ridker PM, Manson JE, Hennekens $\mathrm{CH}$, Buring JE: Vitamin $\mathrm{E}$ in the primary prevention of cardiovascular disease and cancer: the Women's Health Study: a randomized controlled trial. JAMA 2005, 294:56-65.

43. Cook NR, Lee IM, Gaziano JM, Gordon D, Ridker PM, Manson JE, Hennekens $\mathrm{CH}$, Buring JE: Low-dose aspirin in the primary prevention of cancer: the Women's Health Study: a randomized controlled trial. JAMA 2005, 294:47-55.

44. Costenbader $\mathrm{KH}$, Feskanich D, Mandl LA, Karlson EW: Smoking intensity, duration, and cessation, and the risk of rheumatoid arthritis in women. Am J Med 2006, 119:503-511.

45. Karlson EW, Sanchez-Guerrero J, Wright EA, Lew RA, Daltroy LH, Katz JN, Liang $\mathrm{MH}$ : A connective tissue disease screening questionnaire for population studies. Ann Epidemiol 1995, 5:297-302.

46. Arnett FC, Edworthy SM, Bloch DA, McShane DJ, Fries JF, Cooper NS, Healey LA, Kaplan SR, Liang MH, Luthra HS: The American Rheumatism Association 1987 revised criteria for the classification of rheumatoid arthritis. Arthritis Rheum 1988, 31:315-324

47. Hankinson SE, Colditz GA, Hunter DJ, Manson JE, Willett WC Stampfer MJ, Longcope C, Speizer FE: Reproductive factors and family history of breast cancer in relation to plasma estrogen and prolactin levels in postmenopausal women in the Nurses' Health Study (United States). Cancer Causes Control 1995, 6:217-224.

48. Wilke TJ, Utley DJ: Total testosterone, free-androgen index, calculated free testosterone, and free testosterone by analog RIA compared in hirsute women and in otherwise-normal women with altered binding of sex-hormone-binding globulin. Clin Chem 1987, 33:1372-1375.

49. Cox DG, Blanche $\mathrm{H}$, Pearce $\mathrm{CL}$, Calle EE, Colditz GA, Pike MC, Albanes $D$, Allen NE, Amiano P, Berglund G, Boeing $H$, Buring J Burtt N, Canzian F, Chanock S, Clavel-Chapelon F, Feigelson HS, Freedman M, Haiman CA, Hankinson SE, Henderson BE, Hoover R, Hunter DJ, Kaaks R, Kolonel L, Kraft P, LeMarchand L, Lund E, Palli $\mathrm{D}$, Peeters $\mathrm{PH}$, et al:: A comprehensive analysis of the androgen receptor gene and risk of breast cancer: results from the National Cancer Institute Breast and Prostate Cancer Cohort Consortium (BPC3). Breast Cancer Res 2006, 8:R54.

50. Cox DG, Bretsky P, Kraft P, Pharoah P, Albanes D, Altshuler D, Amiano $P$, Berglund $G$, Boeing $H$, Buring J, Burtt N, Calle EE, Canzian F, Chanock S, Clavel-Chapelon F, Colditz GA, Feigelson HS, Haiman CA, Hankinson SE, Hirschhorn J, Henderson BE, Hoover R, Hunter DJ, Kaaks R, Kolonel L, LeMarchand L, Lund E, Palli D, Peeters PH, Pike MC, et al:: Haplotypes of the estrogen receptor beta gene and breast cancer risk. Int J Cancer 2008, 122:387-392.

51. Haiman CA, Dossus L, Setiawan VW, Stram DO, Dunning AM, Thomas G, Thun MJ, Albanes D, Altshuler D, Ardanaz E, Boeing H Buring J, Burtt N, Calle EE, Chanock S, Clavel-Chapelon F, Colditz GA, Cox DG, Feigelson HS, Hankinson SE, Hayes RB, Henderson BE, Hirschhorn JN, Hoover R, Hunter DJ, Kaaks R, Kolonel LN, Le Marchand L, Lenner $P$, Lund $E$, et al:: Genetic variation at the CYP19A1 locus predicts circulating estrogen levels but not breast cancer risk in postmenopausal women. Cancer Res 2007, 67:1893-1897.

52. National Center for Biotechnology Information database of single nucleotide polymorphisms [http:/l www.ncbi.nlm.nih.gov/projects/SNP/]

53. McGrath M, Lee IM, Hankinson SE, Kraft $P$, Hunter DJ, Buring J De Vivo I: Androgen receptor polymorphisms and endometrial cancer risk. Int J Cancer 2006, 118:1261-1268.

54. De Vivo I, Huggins GS, Hankinson SE, Lescault PJ, Boezen M, Colditz GA, Hunter DJ: A functional polymorphism in the promoter of the progesterone receptor gene associated with endometrial cancer risk. Proc Natl Acad Sci USA 2002, 99:12263-12268.

55. De Vivo I, Hankinson SE, Colditz GA, Hunter DJ: A functional polymorphism in the progesterone receptor gene is associated with an increase in breast cancer risk. Cancer Res 2003, 63:5236-5238.

56. Karlson EW, Mandl LA, Hankinson SE, Grodstein F: Do breastfeeding and other reproductive factors influence future risk of rheumatoid arthritis? Results from the Nurses' Health Study. Arthritis Rheum 2004, 50:3458-3467.

57. DerSimonian R, Laird N: Meta-analysis in clinical trials. Control Clin Trials 1986, 7:177-188

58. Kawasaki T, Ushiyama T, Ueyama H, Inoue K, Mori K, Ohkubo I, Hukuda S: Polymorphic CAG repeats of the androgen receptor gene and rheumatoid arthritis. Ann Rheum Dis 1999, 58:500-502.

59. Lo SF, Huang CM, Tsai CH, Chen WC, Lai CC, Tsai Y, Tsai FJ: Androgen receptor gene polymorphism and rheumatoid arthritis in Taiwan. Clin Exp Rheumatol 2006, 24:209-210.

60. Yu SF, Cheng TT, Hsu YH, Lai HM, Chen YC, Chiu CK, Lin KM, Chang C, Chen CJ, Kang HY: Association of tri-nucleotide (CAG and GGC) repeat polymorphism of androgen receptor gene in Taiwanese women with refractory or remission rheumatoid arthritis. Clin Rheumatol 2007, 26:2051-2058. 
61. Takagi $H$, Ishiguro $N$, Iwata $H$, Kanamono $T$ : Genetic association between rheumatoid arthritis and estrogen receptor microsatellite polymorphism. J Rheumatol 2000, 27:1638-1642.

62. Ushiyama T, Mori K, Inoue K, Huang J, Nishioka J, Hukuda S: Association of oestrogen receptor gene polymorphisms with age at onset of rheumatoid arthritis. Ann Rheum Dis 1999, 58:7-10.

63. John S, Myerscough A, Eyre S, Roby P, Hajeer A, Silman AJ, Ollier WE, Worthington J: Linkage of a marker in intron $D$ of the estrogen synthase locus to rheumatoid arthritis. Arthritis Rheum 1999, 42:1617-1620.

64. Raychaudhuri S, Remmers EF, Lee AT, Hackett R, Guiducci C, Burtt NP, Gianniny L, Korman BD, Padyukov L, Kurreeman FA, Chang M, Catanese JJ, Ding B, Wong S, Helm-van Mil AH van der, Neale BM, Coblyn J, Cui J, Tak PP, Wolbink GJ, Crusius JB, HorstBruinsma IE van der, Criswell LA, Amos Cl, Seldin MF, Kastner DL, Ardlie KG, Alfredsson L, Costenbader KH, Altshuler D, et al.: Common variants at CD40 and other loci confer risk of rheumatoid arthritis. Nat Genet 2008, 40:1216-1223.

65. Wellcome Trust Case Control Consortium: Genome-wide association study of 14,000 cases of seven common diseases and 3,000 shared controls. Nature 2007, 447:661-678.

66. Hankinson SE, Manson JE, Spiegelman D, Willett WC, Longcope C, Speizer FE: Reproducibility of plasma hormone levels in postmenopausal women over a 2-3-year period. Cancer Epidemiol Biomarkers Prev 1995, 4:649-654.

67. Hunter DJ, Kraft P, Jacobs KB, Cox DG, Yeager M, Hankinson SE, Wacholder S, Wang Z, Welch R, Hutchinson A, Wang J, Yu K, Chatterjee N, Orr N, Willett WC, Colditz GA, Ziegler RG, Berg CD, Buys SS, McCarty CA, Feigelson HS, Calle EE, Thun MJ, Hayes RB, Tucker M, Gerhard DS, Fraumeni JF Jr, Hoover RN, Thomas G, Chanock SJ: A genome-wide association study identifies alleles in FGFR2 associated with risk of sporadic postmenopausal breast cancer. Nat Genet 2007, 39:870-874.

68. Plenge RM, Seielstad M, Padyukov L, Lee AT, Remmers EF, Ding B, Liew A, Khalili H, Chandrasekaran A, Davies LR, Li W, Tan AK, Bonnard C, Ong RT, Thalamuthu A, Pettersson S, Liu C, Tian C, Chen WV, Carulli JP, Beckman EM, Altshuler D, Alfredsson L, Criswell LA, Amos Cl, Seldin MF, Kastner DL, Klareskog L, Gregersen PK: TRAF1-C5 as a risk locus for rheumatoid arthritis - a genomewide study. N Engl J Med 2007, 357:1199-209.

69. Remmers EF, Plenge RM, Lee AT, Graham RR, Hom G, Behrens TW, de Bakker PI, Le JM, Lee HS, Batliwalla F, Li W, Masters SL, Booty MG, Carulli JP, Padyukov L, Alfredsson L, Klareskog L, Chen WV, Amos Cl, Criswell LA, Seldin MF, Kastner DL, Gregersen PK: STAT4 and the risk of rheumatoid arthritis and systemic lupus erythematosus. N Engl J Med 2007, 357:977-986.

70. Plenge RM, Cotsapas C, Davies L, Price AL, de Bakker PI, Maller J, Pe'er I, Burtt NP, Blumenstiel B, DeFelice M, Parkin M, Barry R, Winslow W, Healy C, Graham RR, Neale BM, Izmailova E, Roubenoff R, Parker AN, Glass R, Karlson EW, Maher N, Hafler DA, Lee DM, Seldin MF, Remmers EF, Lee AT, Padyukov L, Alfredsson L, Coblyn J, et al.: Two independent alleles at $6 \mathrm{q} 23$ associated with risk of rheumatoid arthritis. Nat Genet 2007, 39:1477-1482. 